Sains Malaysiana 50(3)(2021): 595-603

http://dx.doi.org/10.17576/jsm-2021-5003-03

\title{
A Review on Wild Indigenous Eggplant, Terung Asam Sarawak (Solanum lasiocarpum Dunal.)
}

(Suatu Ulasan terhadap Terung Asli Liar, Terung Asam Sarawak (Solanum lasiocarpum Dunal.)

\author{
Albert Ting Koon SoOn \& PHebe Ding*
}

\section{ABSTRACT}

Terung Asam Sarawak (Solanum lasiocarpum Dunal.), also known as terung Dayak or sour eggplant is one of the largest indigenous crops in Sarawak. It has slowly gained a significant commercial importance in Malaysia especially East Malaysia. There have been several studies on Terung Asam Sarawak in the last few decades but mainly focus on plant vernacular and morphology with only some studies focusing on the fruits. The agronomic practices of the plant until fruit postharvest handling have not been comprehensively studied. The information on Terung Asam Sarawak scatters in diverse sources, either local or regional sources, and in several languages too. Therefore, this review attempts to compile these all literature and outline every important finding (from plant origin to planting, fruit postharvest handling, uses and many more) about Terung Asam Sarawak in order to pinpoint the gaps of knowledge. It is hope that this review could assist researchers to focus on the gaps that will help to establish this indigenous eggplant as an important commercial vegetable in tropical countries.

Keywords: Borneo; geographical indication; medicinal plant; Solanaceae; terung Dayak

\section{ABSTRAK}

Terung Asam Sarawak (Solanum lasiocarpum Dunal.), juga dikenali sebagai terung Dayak atau terung masam adalah salah satu tanaman asli yang terbesar di Sarawak. Terung Asam Sarawak mempunyai kepentingan komersial di Malaysia terutamanya di Malaysia Timur. Terdapat beberapa kajian mengenai Terung Asam Sarawak dalam beberapa dekad kebelakangan ini tetapi kebanyakannya bertumpu kepada vernakular dan morfologi tumbuhan ini dengan hanya beberapa kajian yang menumpu kepada buah tumbuhan ini. Maklumat berkaitan dengan tumbuhan ini daripada amalan agronomi hingga kepada pengendalian lepas tuai buah masih belum lengkap. Oleh itu, kajian ini bertujuan untuk mengumpul seтua maklumat kepustakaan dan seterusnya mengemukakan penemuan penting (bermula dengan asalusul tanaman ini hingga ke cara penanaman, pengendalian lepas tuai buah dan penggunaan) mengenai Terung Asam Sarawak untuk mengenal pasti jurang dalam pengetahuan. Dengan ini, para penyelidik diharap dapat menumpukan perhatian kepada jurang tersebut agar dapat membantu untuk menjadikan terung asli ini sebagai tanaman penting di negara tropika.

Kata kunci: Borneo; petunjuk geografi; Solanaceae; terung Dayak; tumbuhan perubatan

\section{INTRODUCTION}

Terung Asam Sarawak (TAS) (Solanum lasiocarpum Dunal.) is one of the indigenous plants or wild fruit vegetables in the state of Sarawak, Malaysia. TAS fruit has a unique eating attributes that enable it to be admired by tourists who visited Sarawak or even outlanders who lived in Sarawak. According to Dayod and Lim (2015), the fruit is a special plant of Borneo which has a unique sour taste. It serves as vegetables and flavouring in local dishes which is popular among the locals. According to Meyer et al. (2014), the native range of $S$. lasiocarpum is from tropical India to Pacific Islands, and it is not an invasive plant to the local ecosystem. It is usually cultivated by local people for fruit production and as ornamental in some rare cases.

Borneo is the third largest island in the world (after Greenland and New Guinea) which has its own unique specialities compared to other parts of the world. Borneo 
consists mainly of Dayak ethnic groups, Malay, Banjar, Orang Ulu, Chinese, and Kadazan-Dusun (Zhang 2016). TAS was said native to Dayak due to the name of the largest indigenous group in Sarawak, but no scientific research has been done to prove the fact. In 2011, The Department of Agriculture Sarawak took the initiative to file TAS under Geographical Indications (GI). The GI certificate was granted on 30 June 2011 by the Malaysian Intellectual Property Organisation (MyIPO), meaning its reputation and characteristics are tied to the region (Shariah 2013).

The golden yellow sour eggplant has several botanically classifications including $S$. lasiocarpum and $S$. ferox. These plants are members of Solanaceae plant family and related to the tomato and pepper which mainly found in Southeast Asian. Eggplants and its closely related Solanum species belonging to the subgenus Leptostemonum are some of the most important vegetable crops in Asia, the Middle and Near East, Southern Europe and Africa (Knapp et al. 2013). Other than the variation in cultures, people, landscapes, natural resources, climate and geographic location, the scientific research on this indigenous eggplant is very limited. The literature of this vegetables is scattered in diverse sources and in several languages. Therefore, this review attempts to compile these all literature and outline every important finding (from plant origin to planting, postharvest handling, uses and many more) about $S$. lasiocarpum.

\section{NAMES AND ORIGIN OF TAS}

There are about 25 known and cultivated food species of Solanum, a genus of the nightshade family Solanaceae all over the world. This includes the potato, tomato, and various eggplants (Samuels 2009). Solanum melongena is generally known as the brinjal or eggplant. Other closely related eggplant species are $S$. aethiopicum (scarlet eggplant) and S. macrocarpon (Gboma eggplant) which are widely cultivated in Africa (Samuels 2012) while $S$. torvum (pea eggplant) and S. lasiocarpum (hairy eggplant) are mainly cultivated in Asia.

There are few scientific synonyms for $S$. lasiocarpum such as $S$. ferox and $S$. aethiopicum. According to Lim (2013a), S. lasiocarpum is commonly known as terung asam (sour brinjal) and terung Dayak (Dayak eggplant) among local people in Sarawak state, Malaysia. It has been traditionally cultivated by some Sarawak local ethnics namely Dayak as an intercrop in hill paddy field (Shariah et al. 2013). It was later being registered with the name of Terung Asam Sarawak (TAS/Sarawak Wild Eggplant) in 2011 (Shariah et al. 2013). Apart from Sarawak, TAS plant is also found in other countries but with different vernacular names. Table 1 shows synonym, common, and vernacular names of TAS used in different regions of world as adopted from Lim (2013b).

Solanum lasiocarpum is found right across tropical region of South and South-East Asia including India, Bangladesh, southern China, Indochina, Indonesia, Malaysia, New Guinea, Solomon Islands, Thailand, and the Philippines (Heiser 1987; Mohanan \& George 2004). On top of these countries, S. lasiocarpum is also grown in southernmost France and Italy (Lim 2013b). Due to their adventive nature, they can adapt rapidly to colonize disturbed ground along roadsides, amongst crops in small-scale cultivations and on the edges of villages as widespread weeds, naturalized or cultivated exotics (Samuels 2012).

On the other hand, S. candidum growing in tropical America (extends north to Mexico and south to Peru) is reported to be very similar to $S$. lasiocarpum of Southeastern Asia (Heiser 1987; Whalen \& Caruso 1983). It was previously suspected that both $S$. lasiocarpum and $S$. candidum might only represent geographical races of a single species (Whalen et al. 1981), and it has been subsequently demonstrated by Heiser (1972) that they are in fact fully inter-crossable. Later, Heiser (1987) reported that artificial hybrids between $S$. candidum and $S$. lasiocarpum are fertile, and it is postulated that $S$. lasiocarpum is resulted from a Spanish introduction of $S$. candidum to Asia. Besides, hybrids of both $S$. candidum and S. lasiocarpum with $S$. repandum are fertile. Heiser (1987) further concluded that S. repandum did not arise from $S$. sessiliflorum but from $S$. lasiocarpum or $S$. candidum. Therefore, S. lasiocarpum as well as its convergence and divergence relatives can be found in various countries, adapting rapidly to the environments and surviving as a wild indigenous eggplant. 
TABLE 1. Synonyms, common and vernacular names of TAS used in different regions of world

\begin{tabular}{|c|c|c|}
\hline Synonyms & Common/English names & Vernacular names \\
\hline $\begin{array}{l}\text { Solanum ferox var. } \\
\text { lasiocarpum (Dunal.) }\end{array}$ & African Bitter Pea-Aubergine & Angola: tungo (Kikongo) \\
\hline Miq. & African Eggplant & Brazil: Jagatú Tunga, Jiló \\
\hline \multirow[t]{2}{*}{$\begin{array}{l}\text { Solanum aethiopicum } \\
\text { Jacq. }\end{array}$} & Bitter Tomato & $\begin{array}{l}\text { Benin: aubergine indigene, tomate amère (French), } \\
\text { gboman (Sahouè), assoukoussé (Watchi) }\end{array}$ \\
\hline & Chinese Scarlet Eggplant & \\
\hline \multirow{16}{*}{$\begin{array}{l}\text { Solanum lasiocarpum } \\
\text { var. } \\
\text { velutinum Dunal. }\end{array}$} & Dayak Eggplant & Central African Republic: Sasa \\
\hline & Ethiopian Eggplant & $\begin{array}{c}\text { Chinese: Xiao Gu Qie, Xiao Ku Fan Qie } \\
\text { (Cantonese) }\end{array}$ \\
\hline & Garden Egg & \\
\hline & Gilo & $\begin{array}{c}\text { Democratic Republic of Congo: ngbagu } \\
\text { (Batiabetuwa) }\end{array}$ \\
\hline & Jamaican Bitter Balls & Ethiopia: Bmy (Amharic) \\
\hline & Kumba, Mock Tomato & French: Africaine, Aubergine Africaine, Aubergine \\
\hline & Sarawak Wild Eggplant & $\begin{array}{c}\text { Djakattou, Petite Bringelle Maronne, Tomate } \\
\text { Amère }\end{array}$ \\
\hline & Scarlet Eggplant & \\
\hline & Shum & $\begin{array}{c}\text { Malaysia: Dayak Eggplant, Sarawak Wild } \\
\text { Eggplant, Sour Brinjal (English), Terong Asam, } \\
\text { Terong Sarawak, Terung }\end{array}$ \\
\hline & Terung Asam & Dayak, Terung Dayak Sarawak, Terung Asam \\
\hline & Terung Dayak & Nigeria: Osun \\
\hline & Terung Dayak Sarawak & Portugues: Jiló, Jagatú Tunga \\
\hline & Terung Sarawak & Senegal: dyahatu (Diola) \\
\hline & Tomato-Fruit Eggplant & Swahili: Ngogwe, Nyanya Chungu \\
\hline & Wild Pea-Aubergine & Swedish: Röd Aubergine \\
\hline & Wild African Aubergine & $\begin{array}{l}\text { Uganda: Ekitulatula (fruit), nakatti (leafy } \\
\text { vegetables) }\end{array}$ \\
\hline
\end{tabular}

\section{PLANT MORPHOLOGY}

According to Lim (2013b) and Shariah et al. (2013), TAS plants are woody perennial herb or annual deciduous shrub. It has tap root system that extend both vertically and laterally with branches and leaves with or without prickles and stellate hairs (Lim 2013b; Shariah et al. 2013). The stem is hairy, thorny and woody, and the plant can grow to $2.5 \mathrm{~m}$ tall, upright, spreading branches, sometimes with tinged light or dark purple (Shariah et al. 2013). The leaf can be characterized as alternate, simple, large green, pinnately veined, ovate to ovate elliptic, prickly with 4-6 short, broadly triangular lobes on each side, with smaller 
secondary lobes, 5-8 cm long petiole with very fine woollike hair (Lim 2013b; Shariah et al. 2013). Besides, the upper leaves are usually smaller, narrower, less lobed and often sub-opposite than those at bottom.

The TAS inflorescence composes 2-6 flowers. The lateral and racemose cyme of inflorescence has short peduncle which may even absent (Lim 2013b). The small flowers are white-coloured, star-shape petals arrangement and hairy outside. The flowers are all bisexual and regular with $4-10$ merous. The pedicel is $2-15 \mathrm{~mm}$ long with its calyx campanulate and lobes of 4-10 mm long. Moreover, its corolla stellate is free and not fused, with a length of 6-15 mm long, white and sometimes pale purple. The stamens are inserted near the base of the corolla tube and alternate with corolla lobes. The filaments are short and thick while anthers are connivent and yellow with opening by terminal pores. The ovary is superior with 2-6-cells and the style as long as or slightly longer than stamens whereas the stigma is small and obtuse (Lim 2013b). TAS fruit is globose to oblate, $5-15 \mathrm{~cm}$ across and ellipsoid, ovoid or fusiform of 2-12 cm long (Lim 2013b). The fruit is also varied from smooth to furrow with many seeds, and the seeds are lenticular to reniform, flattened, 2-5 $\mathrm{mm}$ across with the colour of pale brown or yellow.

\section{GRAFTING OF TAS}

The planting of TAS has been done traditionally via seed sowing directly in the field or polybags or seedling trays in a nursery. After 3 to 4 weeks, the vigorous seedlings sown in seedling trays or polybags can be transplanted to the field (Shariah et al. 2013). However, due to the presence of soil-borne pathogens such as Fusarium wilt, bacterial wilt and Phytophthora in intensively used land, cultivation of TAS plant on that particular land has been very much impractical (Farahzety 2016; Shariah et al. 2013). Therefore, grafting is being done on these susceptible plants to increase their resistance on these pathogens, making harvesting goes earlier, increasing the vigor, yield and quality of the fruits. Collonnier et al. (2001) and Kashyap et al. (2003) reported that S. torvum is resistant to bacterial wilt, mycoplasma, Verticillium spp. and root-knot nematode. Thus, $S$. torvum has been used as a rootstock for S. lasiocarpum (as scion) due to their graft compatibility and the grafting products are promising (Dayod \& Lim 2015). Besides, Semongok Agriculture Research Centre located in Sarawak, Malaysia had successfully grafted and grown $S$. lasiocarpum on S. melongena, a disease resistant rootstock (Shariah et al. 2013).

On the other hand, Paula (2003) discovered that vitrification technique using vitrification solution with sucrose concentration of $0.6 \mathrm{M}$ for $30 \mathrm{~min}$ gave the highest viability of $70 \%$. The seed viability decreased to a small degree after vitrification process and storing in liquid nitrogen for cryopreservation. Through regression analysis, the $S$. lasiocarpum seeds that went through vitrification and stored in liquid nitrogen can last for 10 months, 2 weeks and 4 days. This research contributes to a better preservation method to store $S$. lasiocarpum seeds for future uses.

\section{PHYTOCHEMICAL AND NUTRIENT COMPOSITIONS OF} TAS FRUIT

Fruits and vegetables are known as 'functional food ingredients' since they contain various colourful pigments (Khoo et al. 2011). There are four major classes of plant pigments - chlorophylls, carotenoids, flavonoids, and betalains (Chen 2015; Phebe et al. 2009). In addition, fruits and vegetables also contain various phytochemical substances such as phenolic compounds (flavonoids), nitrogenous compounds (chlorophyll derivatives), tocopherols, carotenoids, and ascorbic acid that show antioxidant activities (Nichenametla et al. 2006). According to Eddine et al. (2016), both phenolics and flavonoids have numerous biological effects, i.e. antioxidant and anti-inflammatory properties. Diets rich in polyphenolic compounds also play an important role in coping against oxidative stress-related disorders (Ding \& Syazwani 2016).

Rahman et al. (2019) stated that fruits and vegetables, including those of Solanum spp., are known to be rich in flavonoids that equipped them with high antioxidant capacities. Among all indigenous fruits and vegetables studied, TAS fruit has received a great amount of attention due to its high nutritional values and antioxidant properties (Voon \& Kueh 1999). TAS fruit contains a high amount of phenolic compounds with powerful free radical scavenging activity (Oszmiański et al. 2014). Rahman et al. (2019) further reported that the TAS water extract contains ample amounts of flavonoids, implying that TAS could be a valuable source of antioxidant compounds.

The TAS fruit is green in colour when it has not ripened yet (Shariah et al. 2013). Harvesting green or yellowish green fruits will shorten its shelf life and poor eating quality with bitter taste. During ripening process, the colour of the fruit will turn from green to yellowish green and finally attain a strong shining chrome yellow. Shariah et al. (2013) further added that the skin of some ripe fruit contains tints of dark purple while in other varieties may show purplish black or cream to brownish black. However, no study has been done to identify the colourful pigments available in both unripe and ripened TAS fruit until now.

There are few reports on TAS fruit nutrient composition. Table 2 shows TAS fruit nutrient composition 
extracted from few sources. Even though the composition varies among sources, TAS fruit is a good source of vitamin $\mathrm{C}$, and it contains calcium, fiber, phosphorus and potassium (Jansen et al. 1996). However, Voon and Kueh
(1999) reported that TAS contains more mineral content but has a lower vitamin $\mathrm{C}$ compared to its cultivated eggplant relatives.

TABLE 2. Nutritional value of $100 \mathrm{~g}$ fresh S. lasiocarpum fruit extracted from three sources

\begin{tabular}{lccc}
\hline \multicolumn{1}{c}{ Food Composition (100 g) } & Voon \& Kueh (1999) & $\begin{array}{c}\text { Leung et al. (1968) } \\
\text { cited in Lim (2013b) }\end{array}$ & $\begin{array}{c}\text { AVRDC (2004) } \\
\text { cited in Lim (2013b) }\end{array}$ \\
\hline Moisture (g) & 89.50 & 90.60 & NI \\
Protein (g) & 1.10 & 1.50 & 1.27 \\
Fat (g) & 0.90 & 0.10 & NI \\
Carbohydrate (g) & 5.80 & 7.20 & NI \\
Crude fibre (g) & 1.70 & 2.00 & 1.42 \\
Ash (g) & 0.80 & NI & 8.60 \\
Mineral Content & & & \\
Phosphate (P) (mg) & 27.00 & 47.00 & NI \\
Potassium (K) (mg) & 188.00 & NI & NI \\
Calcium (Ca) (mg) & 3.00 & 28.00 & 9.00 \\
Magnesium (Mg) (mg) & 6.00 & NI & 0.26 \\
Iron (Fe) (mg) & 0.60 & 1.50 & 0.95 \\
Manganese (Mn) (mg) & 0.20 & NI & NI \\
Copper (Cu) (mg) & 0.10 & NI & NI \\
Zinc (Zn) (mg) & 0.40 & & NI \\
Vitamin & & 8.00 & 12.00 \\
Vitamin C (mg) & 8.00 & & \\
\hline
\end{tabular}

$* \mathrm{NI}=$ No information

\section{USE OF TAS}

Owing to a vast forest area and Dayak people's style of living, various local natural fruits and vegetables including TAS fruit are considered as treasure in their traditional food that further contributed to the uniqueness of Sarawak gastronomic culture (Chee 1997). TAS fruit is served in their daily meals and often cooked with seafood or made into soup with pork, fish or bat meat as shown in Figure 1 (Ting et al. 2017). Irawan et al. (2006) stated that Dayak often collects traditional vegetables such as TAS fruit found in the vast forest area. TAS fruit is added in cooking since it is believed to be able to reduce the fishy odor of the fish or the fattiness of the pork.
TAS fruit is also used in Asam Pedas, or spicy fish dishes. Due to its pleasant sour taste, TAS fruit is often used to substitute tamarind in dishes since they have a similar sour taste. On the other hand, Jais (2016) reported that among all the Asam Pedas recipes in Malaysia, Thailand, and Indian subcontinent, only Asam Pedas Sarawak utilize TAS fruit as one of the souring agents. This recipe makes Asam Pedas Sarawak special among other Asam Pedas recipes because it includes vegetables (Terung Asam) as its main ingredients. The green and immature TAS could also be eaten raw in salads. Other than that, TAS is also consumed as food in other countries such as the Philippines, China, and Bangladesh (Hossan et al. 2012; Meyer et al. 2014). 
In Malaysia, TAS fruit can be processed into a variety of downstream products (Shariah et al. 2013). There are 15 potential downstream products of TAS fruits that commercially available such as fruit jam, fruit juice, dehydrate fruit slices, fruit rolls, cordial drink, ice-cream, Tiung Chips cookies, sambal, cracker, jelly, Gubahan Tiung cake (dehydrated TAS fruit as main ingredient) and even as preserved food in syrup and brine. These downstream products will add a value to this cash crop for commercialisation (Shariah et al. 2013).

In addition, dehydration process is also one of the brilliant methods to turn fresh TAS fruit into dehydrated TAS fruit slice product which can be potentially commercialised in both local and international markets (Razili et al. 2013). $100 \mathrm{~g}$ of dehydrated TAS had higher contents of energy, carbohydrate, crude fiber, ferum, copper, and vitamin $\mathrm{C}$ content if compared to fresh fruit (Razili et al. 2013). The dehydrated fruit slice has a water activity of 0.717 and microbiological shelf life studies showed that the dried produce is still safe for consumption for a minimum of 15 months when stored at room temperature. In addition, the dried fruit product also has an acceptable sensory quality according to a sensory evaluation done on 30 semi-trained panellists. Other than that, Hwong et al. (2019) discovered that freeze-dried ripe TAS fruit has significantly higher crude fibre and ash if compared to freeze-dried unripe TAS. In contrast, freezedried unripe TAS fruit has significantly higher amount of protein and fat if compared to freeze-dried ripe TAS but both freeze-dried fruits are good source of crude fibre, crude protein and mineral.
The documentation of TAS as medicinal plant is still very limited (Garg \& Gupta 1966). Barbosa et al. (1991) stated that TAS has been recorded in the ethnobotanical inventory of medicinal plants due to its medicinal properties that are competent in treating fever, vomiting, sore throat, and gonorrhoea. It has been used in India to treat female sexual disorders whereas its berries and roots have the potential of being anti-bechic, anti-asthmatic, anti-rheumatic, anti-viral, anti-cancer, and spermicidal (Joy et al. 2001). Elkington et al. (2014) reported that the extraction from plant parts of TAS such as leaf, stem, twig, and branch has shown the growth inhibition ability of $71 \%$ on the virulent Mycobacterium tuberculosis $\mathrm{H} 37 \mathrm{R} v$ (Mtb). This research has increased the awareness of the Laos's rich diversity of medicinal plants especially TAS so that these plants can be preserved for more discoveries in the future.

TAS leaf has been used as traditional medicine to treat against allergy, body ache and swelling, skin injuries, and headache (Chander et al. 2014). On the other hand, TAS is used by locals as Chinese herbal medicine for effective curing of cough, bruises, hernia, sore throat, tooth decay, edema as well as having anaesthetic effect (Saikia et al. 2010). Among all TAS plant parts, the leaf contains the highest amount of total phenolic content and antioxidant (Ling 2012). Both water and alcohol extracts of TAS leaf are rich in polyphenolic compounds and have good antioxidant capacity (Shiow et al. 2013). Besides, the extracts can even inhibit the intracellular tyrosinase activity and decrease the melanin content. Therefore, TAS leaf extract is a good antioxidant and has melanoma cell inhibition ability that allow it to be a potential ingredient in skin whitening products.

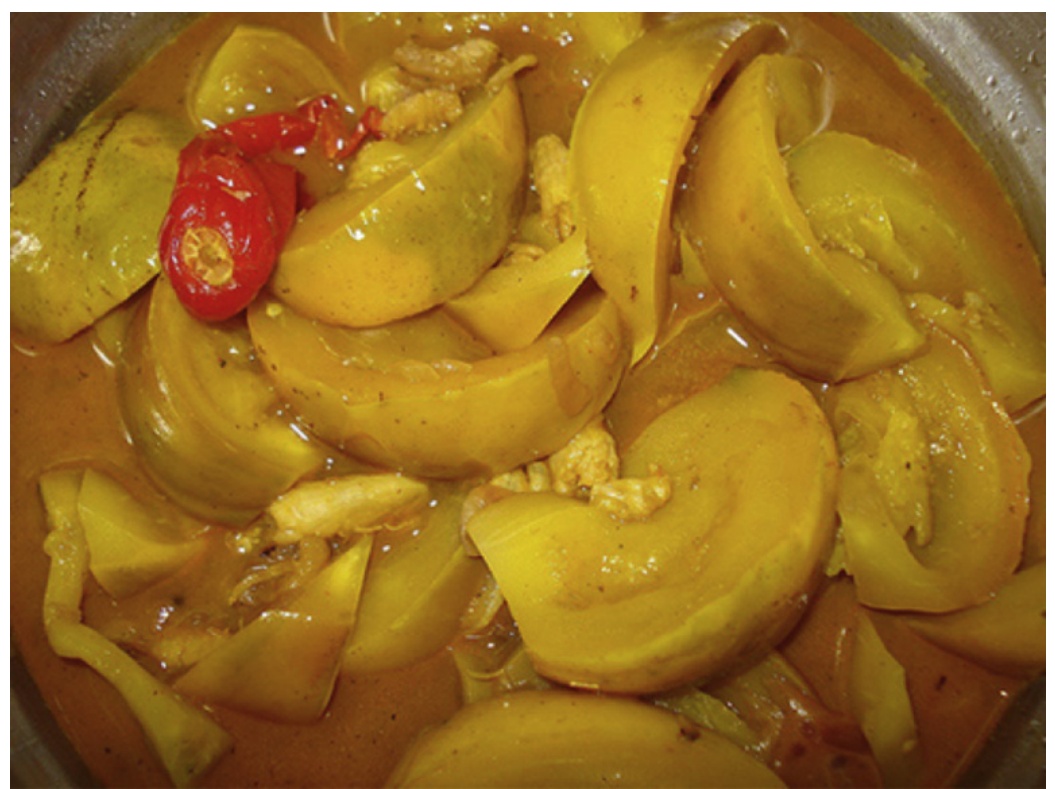

FIGURE 1. TAS fruit made into soup. It tastes pleasantly sour and is served regularly in Sarawakian daily meal (Ting et al. 2017) 
The extract from TAS leaf showed photo-cytotoxic effect where it reduces the in-vitro viability of leukaemic HL60 cells when exposed to $9.6 \mathrm{Jcm}^{-2}$ of a broad-spectrum light at a concentration of $20 \mu \mathrm{gmL}^{-1}$ (Tan et al. 2011). TAS has been used by the Tonchongya tribal community of Roangchaari Upazila of Bandarban district, Bangladesh to treat toothache and syphilis disease (Hossan et al. 2012). Besides leaf, the seed of TAS has been documented to contain stearic, palmitic, oleic, and linoleic acids while the eggplant flesh contains sterol alkaloid solanine (Gupta \& Garg 1966). Recent studies have found that solanine can inhibit movement and invasion of melanoma cells, thus, inhibiting the spread of cancer cells in human body. From these literatures, it seems that TAS is an important crop to human with plenty of goodness.

\section{POSTHARVEST HANDLING}

The maturity of a fruit or vegetable at harvest affects quality within the handling system, and in fact, quality is defined by the buyer (Shewfelt 2014). The handling system from producer to consumer should be conducted with care in order to gain consumer satisfaction. Poor postharvest handling in the supply chain of fresh fruit and vegetables will lead to high amount of losses due to decay caused by pathogens (Ding \& Lee 2019). The determination of the fruit quality and acceptability by the consumer depends on careful attention given from the commodity collection stage until the distribution stage to the buyer (Shewfelt 2014).

In order to maintain the TAS fruit quality and its shelf life, it is notable to conduct harvesting activities on a cool or fine day. The fruits are placed inside a basket and stored in a cool place to avoid physical damages and over-heating situations (Shariah et al. 2013). The colour of TAS fruit is green in the young stage and turns into reddish orange in maturity stage, and this shows that the fruit is ready for harvesting depending on varieties. It can be stored well for up to a month, though the skin will begin to wrinkle due to moisture loss (Shariah et al. 2003). According to Shariah et al. (2013), fully ripe fresh TAS fruits should be stored inside a chiller or refrigerator at $10{ }^{\circ} \mathrm{C}$. By using this storage method, the fruit quality can be maintained and preserved for around 30 days. However, unripe fruits are reported to last for approximately 10 days which could be possibly due to the reason where immature fruits are more susceptible to chilling injury compared to matured or ripe fruit. After these periods of storage time, the fruit will slowly start to wrinkle with the appearance of brown dark spots on the fruit surface, and they will eventually shrink and become soft. Apart from that, not much research has been done to retain TAS fruit quality along postharvest chain.

\section{CONCLUSION}

TAS is an important indigenous crop in Sarawak that has slowly gained a more significant commercial importance in Malaysia especially East Malaysia. Unfortunately, the information from agronomic practices of the plant until postharvest handling of its fruit is rather scarce and incomplete. Therefore, there is a room for researches to study this plant and its fruit so that this indigenous eggplant can be established as an important commercial vegetable in tropical countries.

\section{ACKNOWLEDGEMENTS}

The authors would like to thank UPM for allowing this work to be undertaken in the university compound. This work received the financial aids from the research grant vote 9629600.

\section{REFERENCES}

Asian Vegetable Research Development Center (AVRDC). 2004. African scarlet eggplant. The AVRDC Nutrient Database. AVRDC - The World Vegetable Database Center. http://avrdcnutrition.gtdtestsite.comoj.com/nutrition/about. php.

Barbosa, F.J.M., Agra, M.F., Oliseeira, R.A., Paulo, M.Q., Trolin, G., Cunha, E.V., Ataide, J.R. \& Bhattacharyya, J. 1991. Chemical and pharmacological investigation of Solanum species of Brazil - A search for solasodine and other potentially useful therapeutic agents. Memórias do Instituto Oswaldo Cruz 86(2): 189-191.

Chander, M.P., Kartick, C., Gangadhar, J. \& Vijayachari, P. 2014. Ethno medicine and healthcare practices among Nicobarese of Car Nicobar - An indigenous tribe of Andaman and Nicobar Islands. Journal of Ethnopharmacology 158(Part A): $18-24$.

Chee, T.B. 1997. Indigenous people, the state and ethnogenesis: A study of the communal associations of the "Dayak" communities in Sarawak, Malaysia. Journal of Southeast Asian Studies 28(2): 263-284.

Chen, C.X. 2015. Pigments in Fruits and Vegetables. New York: Springer. pp. 165-188.

Collonnier, C., Fock, I., Kashyap, V., Rotino, G.L. Daunay, M.C., Lian, Y., Mariska, I.K., Rajam, M.V., Servaes, A., Ducreux, G. \& Sihachakr, D. 2001. Applications of biotechnology in eggplant. Plant Cell, Tissue and Organ Culture 65(2): 91-107.

Dayod, M. \& Lim, L. 2015. Graft compatibility between Solanum lasiocarpum and Solanum torvum: As a potential tool to mitigate soil-borne diseases in Sarawak. In 4th International Conference on Agriculture \& Horticulture Conference Series

Ding, P. \& Lee, Y.L. 2019. Use of essential oils for prolonging postharvest life of fresh fruits and vegetables. International Food Research Journal 26(2): 363-366. 
Ding, P. \& Syazwani, S. 2016. Physicochemical quality, antioxidant compounds and activity of MD-2 pineapple fruit at five ripening stages. International Food Research Journal 23(2): 549-555.

Eddine, L.S., Djamila, B. \& Redha, O.M. 2016. Solvent $\mathrm{pH}$ extraction effect on phytochemical composition and antioxidant properties of Algerian Matricaria pubescens. Journal of Pharmacy Research 10(2): 106-112.

Elkington, B.G., Sydara, K., Newsome, A., Hwang, C.H., Lankin, D.C., Simmler, C., Napolitano, J.G., Ree, R., Graham, J.G., Gyllenhaal, C., Bouamanivong, S., Souliya, O., Pauli, G.F., Franzblau, S.G. \& Soejarto, D.D. 2014. New finding of an anti-TB compound in the genus Marsypopetalum (Annonaceae) from a traditional herbal remedy of Laos. Journal of Ethnopharmacology 151(2): 903-911.

Farahzety, A.M. 2016. Current status and future prospects of vegetable grafting in Malaysia. In Conference: International Workshop on Grafting to Improve FruitVegetable Production Food and Fertilizer Technology Center (FFTC).

Garg, S.K. \& Gupta, D.R. 1966. Chemical examination of the seed fat of Solanum ferox L. Fette, Seifen, Anstrichmittel 68(6): 449-450.

Gupta, D. \& Garg, S. 1966. Isolation of solanine from the fruits of Solanum ferox. Naturwissenschaften 53(4): 108-109.

Heiser, C.B. 1987. Origins of Solanum lasiocarpum and $S$. repandum. American Journal of Botany 74(7): 1045-1048.

Heiser, C.B. 1972. The relationships of the Naranjilla, Solanum quitoense. Biotropica 4(2): 77-84.

Hossan, M.S., Roy, P., Seraj, S., Mou, S.M., Monalisa, M.N., Jahan, S., Khan, T., Swarna, A., Jahan, R. \& Rahmatullah, M. 2012. Ethnomedicinal knowledge among the Tongchongya tribal community of Roangchaari Upazila of Bandarban district, Bangladesh. American-Eurasian Journal of Sustainable Agriculture 6(4): 349-359.

Hwong, C.S., Koh, C.C. \& Hii, S.L. 2019. Nutritional composition of unripe and ripe freeze-dried Terung Asam from Sarawak. Journal of Social Science and Humanities 16(3): 1-6.

Irawan, D., Wijaya, C.H., Limin, S.H., Hashidoko, Y., Osaki, M. \& Kulu, I.P. 2006. Ethnobotanical study and nutrient potency of local traditional vegetables in Central Kalimantan. Tropics 15(4): 441-448.

Jais, A.S. 2016. Deconstructing Malay delicacies "Asam Pedas": Critical ingredients and flavor profile. In Proceedings of Agro Food and Biotechnology Festival. pp. 1-10.

Jansen, P.C.M., Wilk, C.V.D. \& Hetterscheid, W.L.A. 1996. Plants yielding non-seed carbohydrates. PROSEA: Plant Resources of South-East Asia 9: 45-50.

Joy, P.P., Thomas, J., Mathew, S. \& Skaria, B.P. 2001. Medicinal plants. Tropical Horticulture 28: 449-632.

Kashyap, V., Kumar, S.V., Collonnier, C., Fusari, F., Haicour, R., Rotino, G.L., Sihachakr, D. \& Rajam, M.V. 2003. Biotechnology of eggplant. Scientia Horticulturae 97(1): $1-25$.

Khoo, H.E., Prasad, K.N., Kong, K.W., Jiang, Y. \& Ismail, A. 2011. Carotenoids and their isomers: Colour pigments in fruits and vegetables. Molecules 16(2): 1710-1738.
Knapp, S., Vorontsova, M.S. \& Prohens, J. 2013. Wild relatives of the eggplant (Solanum melongena L.: Solanaceae): New understanding of species names in a complex group. PLoS ONE 8(2): 1-12.

Leung, W.T.W., Busson, F. \& Jardin, C. 1968. Food Composition Table for Use in Africa. Rome: FAO.

Lim, T.K. 2013a. Solanum aethiopicum. Edible Medicinal and Non-medicinal Plants. Netherlands: Springer.

Lim, T.K. 2013b. Solanum lasiocarpum. Edible Medicinal and Non-medicinal Plants. Netherlands: Springer.

Ling, Y.S. 2012. Study on the antioxidant constituents of the leaves of Solanum lasiocarpum. Ph.D. Thesis. Nanfang University of Technology (Unpublished).

Meyer, R.S., Bamshad, M., Fuller, D.Q. \& Litt, A. 2014. Comparing medicinal uses of eggplant and related Solanaceae in China, India, and the Philippines suggests the independent development of uses, cultural diffusion, and recent species substitutions. Economic Botany 68(2): 137-152.

Mohanan, N. \& George, K.V. 2004. Cultivated crops and their wild relatives of Kerala State. In Conference: National Seminar on Biodiversity Conservation and Environment Management, Catholicate College, Pathanamthitta, Kerala. pp. 82-87.

Nichenametla, S.N., Taruscio, T.G., Barney, D.L. \& Exon, J.H. 2006. A review of the effects and mechanisms of polyphenolics in cancer. Critical Review in Food Science and Nutrition 46(2): 161-183.

Oszmiański, J., Kolniak-Ostek, J. \& Wojdyło, A. 2014. Characterization of phenolic compounds and antioxidant activity of Solanum scabrum and Solanum burbankii berries. Journal of Agricultural and Food Chemistry 62(7): 1512-1519.

Paula, M.P. 2003. Cryopreservation of Solanum lasiocarpum Dunal using vitrification technique. Ph.D. Thesis. Universiti Malaysia Sarawak (Unpublished).

Phebe, D., Chew, M.K., Suraini, A.A., Lai, O.M. \& Janna, O.A. 2009. Red-fleshed pitaya (Hylocereus polyrhizus) fruit colour and betacyanin content depend on maturity. International Food Research Journal 16(2): 233-242.

Rahman, Z.A., Zaidan, M.W.A.M., Othman, A.N., Ahmad, M.A., Simoh, S. \& Ismail, M.A.H. 2019. Optimizing extraction of phenolics and flavonoids from Solanum ferox fruit. Natural Science 11(4): 99-105.

Razili, R.M., Umar, S. \& Sallehuddin, R. 2013. Quality product from Terung Asam (Solanum lasiocarpum Dunal): A popular indigenous fruit-vegetable of Sarawak, Malaysia. ISHS Acta Horticulturae 1088: 569-572.

Saikia, B., Borthakur, S. \& Saikia, N. 2010. Medico-ethnobotany of Bodo tribals in Gohpur of Sonitpur district, Assam. Indian Journal of Traditional Knowledge 9(1): 52-54.

Samuels, J. 2009. The Solanaceae-novel crops with high potential. Organic Grower 9: 32-34.

Samuels, J. 2012. Genetically Engineered Bt. Brinjal and the Implications for Plant Biodiversity. Cornwall, United Kingdom: Novel Solanaceae Crops Project.

Shariah, U. 2013. "Terung Asam Sarawak", a geographical indication (GI)-registered product of Sarawak. New Sunday Tribune. https://data.sarawak.gov.my/home/data/resource 
download/a28db33a-862f-465d-927a-367d9ad84445/. Access on 12 August 2019.

Shariah, U., Rajmah, M.R., Wong, M.H. \& Nur, N.H. 2013. Terung Asam Sarawak Technology Package. Sarawak, Malaysia: Department of Agriculture Sarawak.

Shewfelt, R.L. 2014. Measuring quality and maturity. In Postharvest Handling, 3rd ed, edited by Florkowski, W., Shewfelt, R., Prussia, S. \& Banks, N. United States: Elsevier.

Shiow, C.H., Miao, C.L., Yi, Y.M., Ya, D.C., Chin, W.C., Jr., Y.Z., Ching, W.Y. \& Chiu, L.C. 2013. The study of Rubus formosensis and Solanum lasiocarpum on skin-whitening activity. Chia-Nan Annual Bulletin 39: 97-106.

Tan, P.J., Ong, C.Y., Danial, A., Yusof, H.M., Neoh, B.K. \& Lee, H.B. 2011. Cyclic tetrapyrrolic photosensitisers from the leaves of Phaeanthus ophthalmicus. Chemistry Central Journal 5: 32.

Ting, H., Tan, S.R. \& John, A.N. 2017. Consumption intention toward ethnic food: Determinants of Dayak food choice by Malaysians. Journal of Ethnic Foods 4(1): 21-27.
Voon, B.H. \& Kueh, H.S. 1999. The nutritional value of indigenous fruits and vegetables in Sarawak. Asia Pacific Journal of Clinical Nutrition 8(1): 24-31.

Whalen, M.D. \& Caruso, E.E. 1983. Phylogeny in Solanum sect. Lasiocarpa (Solanaceae): Congruence of morphological and molecular data. Systematic Botany 8(4): 369-380.

Whalen, M.D., Costich, D.E. \& Heiser, C.B. 1981. Taxonomy of Solanum Section Lasiocarpa. Ithaca, New York: Bailey Hortorium.

Zhang, C.Y. 2016. Borneo - A future gem of Asia-Pacific. In The 33rd Annual Pan-Pacific Conference PPBA.

Faculty of Agriculture

Universiti Putra Malaysia

43400 UPM Serdang, Selangor Darul Ehsan

Malaysia

*Corresponding author; email: phebe@upm.edu.my

Received: 29 January 2020

Accepted: 13 August 2020 